\title{
Poverty, Inequality, and Development in the Philippines: Official Statistics and Selected Life Stories
}

\author{
David Michael M. San Juan and Prince Jhay C. Agustin ${ }^{1}$
}

\begin{abstract}
Mainstream academia's and neoliberal economists' failure to exhaustively explain the roots of the 2008 crisis and point a way towards how the world can fully recover from it, made radical theories of poverty and income inequality more popular and relevant as ever. Official World Bank statistics on poverty and their traditional measurements are put into question and even an IMF-funded study admits that instead of delivering growth, neoliberalism has not succeeded in bringing economic development to the broadest number of people, as massive poverty and income inequality abound in many countries, more especially in the developing world. Drawing from theories on surplus value, labor exploitation, and economic dependency, this paper will present an updated critique of the official poverty line in the Philippines and how official statistics mask the true extent of poverty in the country, thereby figuratively many faces of poverty hidden if not obliterated; analyze the link between poverty and income inequality within the country's neocolonial set-up; and present summarized selected life stories of ambulant vendors, mall personnel, fast food workers, cleaners, security guards and other typical faces of poverty in the Philippines' macro-economically rich capital region - Metro Manila - which serve as fitting counterpoints to the official narrative. Such discussion will be the paper's springboard in presenting an alternative plan towards sustainable development of the Philippines.
\end{abstract}

Keywords: poverty level, inequality, globalization,

\section{Introduction}

Mainstream definitions and measurements of poverty levels have come under increasing scrutiny and criticism as radical theories of poverty and income inequality recover their popularity, after more than a decade of neoliberalism's failure to resolve the 2008 crisis that hit America and segments of Europe. Reddy \& Lahoti (2016) remark that the "criticisms that have been levelled at the (World) Bank's methodology since the 1990s over key technical questions-PPPs, inflation measures, price variations within countries (in particular the differing costs in rural and urban areas) and the merits of income versus consumption data" remain relevant even after World Bank economists increased the international poverty line from $\$ 1.02$ to $\$ 1.90$ in 2014. Meanwhile, Hickel (2016) minces no words in explaining how the United Nations' "MDGs have used targeted statistical manipulation to make it seem as though the poverty and hunger 
trends have been improving when in fact they have worsened. In addition, the MDGs use definitions of poverty and hunger that dramatically underestimate the scale likely of these problems. In reality, around four billion people remain in poverty today, and around two billion remain hungry - more than ever before in history, and between two and four times what the UN would have us believe." Even World Bank-friendly experts like Chandy and Karas (2016) admit that there are "contradictions" in official poverty data and "it is surprising that the empirical basis for country and global poverty numbers is rather weak." With regard to incongruities, a 2017 statement on poverty in the USA by Prof. Philip Alston, United Nations Special Rapporteur on extreme poverty and human rights - which count 40 million Americans in poverty, belies the World Bank's poverty headcount ratio for the USA, which is just at a measly $1 \%$.

Official World Bank statistics on poverty and their traditional measurements are put into question (Moatsos, 2017) and calls are made for the "measurement of poverty in both monetary and non-monetary dimensions" so as to "reduce poverty in all its forms" (Saunders, 2018). Even an IMF-funded study (Ostry et al., 2016) admits that instead of delivering growth, neoliberalism has not succeeded in bringing economic development to the broadest number of people, as massive poverty and income inequality abound in many countries, more especially in the developing world (San Juan, 2017).

Drawing from theories on surplus value, labor exploitation, and economic dependency, this paper will present an updated critique of the official poverty line in the Philippines and how official statistics mask the true extent of poverty in the country, thereby figuratively many faces of poverty hidden if not obliterated; analyze the link between poverty and income inequality within the country's neocolonial set-up; and present summarized selected life stories of ambulant vendors, mall personnel, fast food workers, cleaners, security guards and other typical faces of poverty in the Philippines' macro-economically rich capital region - Metro Manila - which serve as fitting counterpoints to the official narrative. Such discussion will be the paper's springboard in presenting an alternative plan towards sustainable development of the Philippines.

\section{Critique of Official Philippine Poverty Statistics}

Official Philippine poverty statistics should be subjected to a rigorous critique, if the real extent of poverty is to be revealed as a springboard for realizing the actual breadth and depth of poverty as a national and international problem, which is the first step towards genuinely resolving the problem.

At the outset, the critique could begin with backing up Chossudovsky's (2018) straightforward way of describing official poverty figures in the Philippines as something that "have been manipulated" as the Philippine government only appears to have "adopted the one dollar a day World Bank criterion" while failing "to account for 
inflation in both the 2012 and 2015 estimates." Such official Philippine poverty statistics focus too much on food poverty and fails to adequately encompass other essential people's needs. Moreover, these statistics don't consider the fact that families can be food-rich (with incomes deemed officially high enough to cover the minimum food threshold set by national authorities) and actually poor at the same time.

Even the official food poverty threshold cannot accurately measure real levels of food poverty, as it has been shockingly and significantly redefined in 2009. Such recalibration of the food poverty threshold imposed lower and thus cheaper dietary requirements for Filipino citizens, thereby artificially lowering down the official poverty statistics. The new food poverty threshold was so laughable that it was eloquently criticized even by a mainstream statistician who correctly spotted the wide gap between the old and the new methodology for measuring food poverty (Mangahas, 2011a and 2016). For example, Mangahas (2011b) notes that the new menu for the food threshold includes "no meat" for the poor (see Table 1), despite the Philippine government's inclusion of meat in the country's "Daily Nutritional Guide Pyramid" released by the Food and Nutrition Research Institute (see Figure 1).

Table 1. Old and New Menu in the Philipppines' Official Food Poverty Threshold (Mangahas, 2011b)

\begin{tabular}{|c|c|c|c|}
\hline $\begin{array}{ll} & \mathbf{M} \\
\text { eal } & \\
\end{array}$ & Old Menu & New Menu & Changes \\
\hline eakfast & $\begin{array}{ll}\text { - } & \text { Tomato omelette } \\
\text { - } & \text { Coffee for adults } \\
\text { - } & \text { Milk for children } \\
\text { - } & \text { Fried rice }\end{array}$ & $\begin{array}{ll}\text { - } & \text { Scrambled egg } \\
\text { - } & \text { Coffee with milk } \\
\text { - } & \text { Boiled rice }\end{array}$ & $\begin{array}{ll}\text { - } & \begin{array}{l}\text { Elimination of } \\
\text { tomato }\end{array} \\
\text { - } & \begin{array}{l}\text { Elimination of milk } \\
\text { for children }\end{array} \\
\text { - } & \begin{array}{l}\text { Substitution of fried } \\
\text { rice with boiled rice }\end{array} \\
\end{array}$ \\
\hline nch &  & 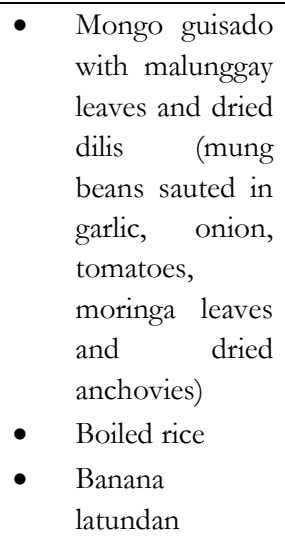 & $\begin{array}{ll}\text { - } & \text { Elimination of fish } \\
\text { - } & \text { Substitution of } \\
\text { small shrimps with } \\
\text { dried dilis }\end{array}$ \\
\hline Di & - $\quad$ Pork adobo (pork & - $\quad$ Fried & Elimination of pork \\
\hline
\end{tabular}




\begin{tabular}{|c|c|c|c|}
\hline nner & $\begin{array}{l}\text { cooked in vinegar, } \\
\text { soy sauce, garlic, } \\
\text { and black pepper) } \\
\text { - } \quad \text { Pechay guisado } \\
\text { (sauted bok choy) } \\
\text { - Boiled rice } \\
\text { - Banana latundan }\end{array}$ & 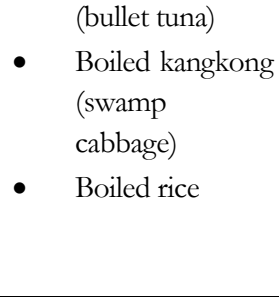 & 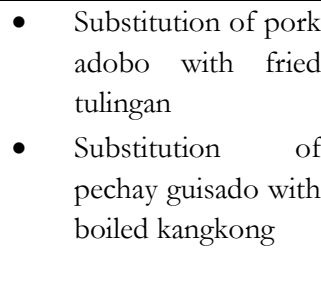 \\
\hline $\begin{array}{ll} & \text { Sn } \\
\text { acks } & \end{array}$ & $\begin{array}{l}\text { - Pandesal (small } \\
\text { common bread) } \\
\text { with margarine }\end{array}$ & - $\quad$ Plain pandesal & $\begin{array}{l}\text { - Elimination } \\
\text { margarine }\end{array}$ \\
\hline
\end{tabular}

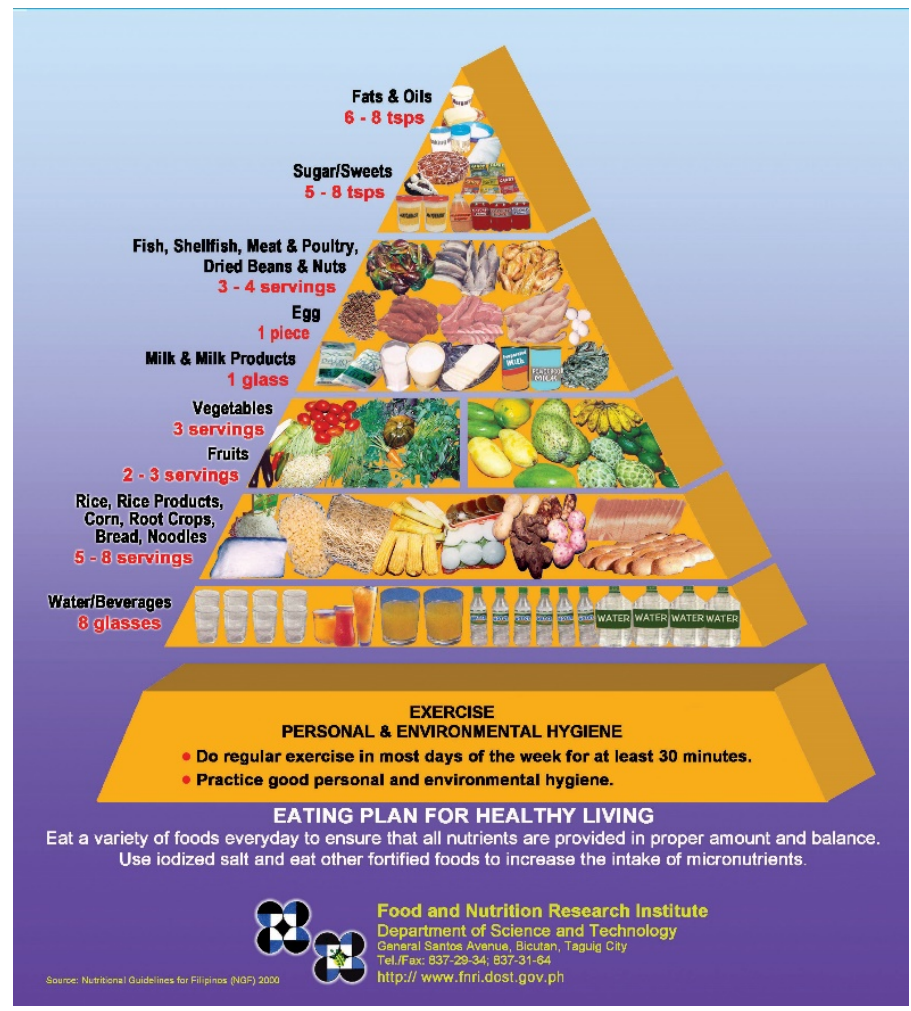

Fig. 1 Daily Nutritional Guide Pyramid for Adults (Food and Nutrition Research Institute, c. 2018)

As per the latest (2015) official poverty statistics released by the Philippine Statistics Authority (PSA), "a family of 5 needed at least 9,064 pesos (US \$174) to meet both basic food and non-food needs monthly" of which 6,329 pesos (US \$122) is allotted "to meet basic food needs," allowing only for a meager 2,735 pesos (US \$ 53) for "non-food needs." Such pitiful amount for the non-food needs won't cover all the items enumerated by a 2007 resolution of the country's National Statistical Coordination Board 
(NSCB): 1) clothing and footwear; 2) housing; 3) fuel, light, water; 4) maintenance and minor repairs; 5) rental of occupied dwelling units; 6) medical care; 7) education; 8) transportation and communication; 9) non-durable furnishings; 10) household operations; and 11) personal care \& effects." It must be noted that the Philippine government's categories of essential non-food items doesn't include any item related to leisure/entertainment, despite the fact that the United Nations' Universal Declaration of Human Rights (for which the Philippines voted in favor) mentions "the right to rest and leisure..." in Article 24. Other entities such as the European Union's Eurostat (2015) includes leisure in their "quality of life indicators." This laudable inclusion is a reflection of the generally accepted idea that leisure is an essential human need (Leversen et al., 2012, and Veal, 2015). Thus, a genuinely holistic poverty threshold should certainly include leisure-related items in the essential non-food items.

\section{Alternative Measures of Poverty}

Poverty thresholds should always include thresholds on essential non-food needs of the people. Poor citizens are those whose incomes are below the real cost of living. To help present a better view of real poverty rates in the country, the current researchers made an updated (and still very conservative) estimate of the government's categories of non-food items based on actual Metro Manila prices:

Table 2. Detailed Monthly Cost Estimate of Non-Food Items for A Family of 5 In the Philippines (2018)

\begin{tabular}{|c|c|c|c|}
\hline $\begin{array}{l}\text { Non } \\
\text {-Food Item }\end{array}$ & $\begin{array}{l}\text { Co } \\
\text { st for a } \\
\text { Family of } 5\end{array}$ & Assumption/Explanation & Source of Data \\
\hline $\begin{array}{lr} & \text { Clot } \\
\text { hing } & \text { and } \\
\text { footwear } & \end{array}$ & pesos & $\begin{array}{l}\text { Assuming the family needs only } \\
\text { two sets of clothes and footwear per year } \\
\text { and costs are spread per month } \\
\text { Cheapest price for t-shirt, } \\
\text { blouse, skirt, shorts and jeans (only for } \\
\text { the father) in the popular Divisoria } \\
\text { Market } \\
\text { Cheapest price for shoes (only } \\
\text { for mother and father) and slippers (for } \\
\text { the whole family) in the popular Divisoria } \\
\text { Market }\end{array}$ & $\begin{array}{l}\text { Price watch of } \\
\text { the government TV } \\
\text { Channel, } \\
\text { Television/PTV } \\
\text { and 2016b) }\end{array}$ \\
\hline $\begin{array}{l}\text { Housing or } \\
\text { rental of } \\
\text { occupied } \\
\text { dwelling units }\end{array}$ & 00 pesos & $\begin{array}{l}\text { Cheapest monthly rent for } \\
\text { unfurnished studio unit in Manila } \\
\text { (apartment prices are definitely higher) }\end{array}$ & $\begin{array}{l}\text { Researchers' } \\
\text { own canvassing of April } \\
2018 \text { rent prices in Manila } \\
\text { (listed prices in online rent }\end{array}$ \\
\hline
\end{tabular}




\begin{tabular}{|c|c|c|c|}
\hline & & & advertisements are higher) \\
\hline Fuel & $\begin{array}{r}415 \\
\text { pesos (LPG) }\end{array}$ & 7-kg. LPG tank & $\begin{array}{l}\text { Department of } \\
\text { Energy (2018) }\end{array}$ \\
\hline Light & $\begin{array}{lr} & 1,2 \\
55 & \text { pesos } \\
\text { (light } & \text { and } \\
\text { basic } & \\
\text { applicances) }\end{array}$ & $\begin{array}{l}\text { 3-hour daily use of one } \\
\text { florescent lamp; daily use of small } \\
\text { refrigerator; 15-hour/day use of ceiling } \\
\text { fan; 8-hour/day use of small TV }\end{array}$ & $\begin{array}{l}\text { Manila Electric } \\
\text { Company } \quad \text { (MERALCO) } \\
\text { online app (2018) }\end{array}$ \\
\hline Water & $\begin{array}{l}122 \\
\text { pesos (water, } \\
\text { not for } \\
\text { drinking) } \\
\\
\text { pesos } \\
\text { (drinking } \\
\text { water) }\end{array}$ & $\begin{array}{c}10 \text { cubic meters of water } \\
20 \text { gallons of drinking } \\
\text { water/month (common brands) }\end{array}$ & $\begin{array}{l}\text { Maynilad Bill } \\
\text { Calculator (2018) } \\
\text { Researchers' } \\
\text { own canvassing of April } \\
2018 \text { prices in Manila }\end{array}$ \\
\hline $\begin{array}{l}\text { Maintenance } \\
\text { and minor } \\
\text { repairs }\end{array}$ & pesos & $\begin{array}{l}\text { Monthly cost of low-cost } \\
\text { plumbing repair service (assuming repair } \\
\text { is only done once a year) }\end{array}$ & Gawin Group (2017) \\
\hline Medical care & pesos & $\begin{array}{l}\text { Monthly cost of QualiMed } \\
\text { AKcess Card for the family, "an } \\
\text { affordable primary care health card used } \\
\text { to avail of free healthcare service } \\
\text { inclusions and discounts on outpatient or } \\
\text { ambulatory care needs" }\end{array}$ & QualiMed (c.2018) \\
\hline Education & 00 pesos & $\begin{array}{l}\text { Covers only cheap school } \\
\text { lunches for } 3 \text { children per month } \\
\text { (assuming that children study in public } \\
\text { schools where tuition is free and books } \\
\text { are provided for by the government) }\end{array}$ & $\begin{array}{ll}\text { Researchers' } & \text { own } \\
\text { canvassing of April } 2018 \\
\text { prices in Manila }\end{array}$ \\
\hline $\begin{array}{l}\text { Tran } \\
\text { sportation and } \\
\text { communication }\end{array}$ & 480 & $\begin{array}{l}\text { Covers only minimum jeepney } \\
\text { fares per month for } 1 \text { person (assuming } \\
\text { that the family lives in the town center } \\
\text { and only the father commutes daily to } \\
\text { work) } \\
\text { Covers only cellphone load for } \\
\text { two people (one-month unlimited calls to } \\
\text { the same network and unlimited text to all }\end{array}$ & $\begin{array}{l}\text { Fare price set by } \\
\text { the government }\end{array}$ \\
\hline
\end{tabular}




\begin{tabular}{|c|c|c|c|}
\hline & pesos & networks) & \\
\hline $\begin{array}{l}\text { Non } \\
\text {-durable } \\
\text { furnishings }\end{array}$ & 0 & $\begin{array}{l}\text { Prices of covered tems are } \\
\text { difficult to estimate; hence no estimates } \\
\text { are given }\end{array}$ & $\mathrm{N} / \mathrm{A}$ \\
\hline $\begin{array}{l}\text { Hou } \\
\text { sehold } \\
\text { operations }\end{array}$ & 00 pesos & $\begin{array}{l}\text { Cheap laundry expenses (for } 80 \\
\text { kilos of laundry/month) } \\
\text { Actual costs for household } \\
\text { operations are higher as prices of other } \\
\text { covered items and services are difficult to } \\
\text { estimate; hence only estimates for laundry }\end{array}$ & $\begin{array}{l}\text { Researchers' } \\
\text { own canvassing of April } \\
2018 \text { prices in Manila }\end{array}$ \\
\hline \begin{tabular}{l}
\multicolumn{2}{r}{ Pers } \\
onal care \& \\
effects
\end{tabular} & pesos & $\begin{array}{l}\text { Bath soap (family size) at } 4 \text { bars } \\
\text { per month }\end{array}$ & $\begin{array}{l}\text { Department of } \\
\text { Trade and Industry (2018) }\end{array}$ \\
\hline $\begin{array}{ll} & \text { TO } \\
\text { TAL } & \\
\end{array}$ & $\begin{array}{l}18, \\
(\mathrm{U}\end{array}$ & $\begin{array}{l}\text { pesos } \\
347)\end{array}$ & \\
\hline
\end{tabular}

The researchers' figures for a conservative but reliable poverty threshold is thus pegged at 24,420 pesos per month for a family of five. Such amount is more than double the government's official poverty threshold, and a bit comparable with the 33,570-peso monthly living wage for a family of six as computed (albeit without available details on costs) by Ibon Databank (2017), an independent think tank. Websites such as numbeo.com that produce statistics through crowdsourcing, can also help set the poverty threshold. As of April 2018, in what could be dubbed as the upper limit of cost of living in Manila for a four-person family, numbeo.com pegs the figure at 90,858.11 pesos without rent, while monthly rents for one-bedroom apartments range from $12,005.95$ to $23,076.92$ pesos. Such estimates are actually closer to another government agency's statistics.

The National Economic Development Authority (NEDA) did release its own statistics on what income is needed for a family of four to be able to live comfortably in the Philippines. Its 120,000-peso monthly figure impressively goes beyond the official poverty threshold, but the same agency downplayed the possibility of the government working towards the concretization of such ideal, emphasizing in its launch that it is just a "vision" and "not meant to be prescriptive. This is just saying where Filipinos want to go..." (Dela Paz, 2016). Nevertheless, NEDA also whimsically claims that the Philippines can attain upper middle-income status as early as 2019 (Leyco, 2018), despite the fact that the government is actually still in denial with regard to the breadth and depth of poverty in the Philippines.

Countless life stories of globalization's discontents, life stories of marginalized citizens whose lives are not documented by the government's limited statistics, life 
stories of poor citizens in one of Southeast Asia's worst countries with regard to outward migration, poverty, and unemployment rates, could serve as counterpoints to the official narrative and reveal the hidden faces of poverty in the country.

\section{Life Stories of Globalization's Discontents}

The current researchers have interviewed - using the indigenous approach "pagtatanong-tanong" or an "improvised informal, unstructured interview" and "pakikipagkuwentuhan" or "story telling" or "informal conversations" (Pe-Pua and Protacio-Marcelino, 2000) - an ambulant vendor, a mall personnel, a fast food worker, a cleaner, and a security guard: typical faces of poverty in the Philippines' macroeconomically rich capital region whose life stories weave a collective tale that challenge the official government narrative and reveal aspects of poverty that are rarely discussed in official documents. They were specifically chosen as they were already encountered by the researchers, a number of times even before they were interviewed for this article.

Citations from interviewees were translated from Filipino. All of them have incomes below NEDA's definition of a comfortable family income, below the researchers' own computed poverty threshold, and below IBON Databank's family living wage threshold. Conversations with them were held from December 2017 to March 2018, during their free time. Interviewees' first names were stated as authorized by them (unless otherwise stated, in which case researchers have used a knick name).

Most of the interviewees are also part of the dominant sector in the Philippine labor force - the service sector. According to the Philippine Statistics Authority (2017), "56.3 percent of the total employed in 2017" are from the services sector. San Juan (2016) described how the Philippines' service sector-driven economy is rooted in the country's dependence on developed/First World economies, a system that “...is more favorable to developed/ capital-rich countries because 1) developed nations' investments in developing countries earn profits which the former typically repatriate, rather than reinvest in the latter; 2) developed countries control multilateral financial institutions such as the IMF, World Bank, and even the biggest private banks that are capable of bankrolling or frustrating any effort towards industrialization contemplated by progressive developing countries' governments; 3) technology transfers on a massive scale seldom happens, hence developed countries tend to retain a monopoly on innovations vital to the growth of the manufacturing sector; 4) the bulk price of the developing countries' main exports (raw materials and semi-manufactured goods) is lower than the bulk price of their typical imports from developed countries (technology/ machinery and high-value products); 5) the migration of workers and professionals from developing countries to the developed countries depletes the former's human resources 
which they need to free themselves from poverty and dependency; and 6) the education system of developing countries is aligned with the needs of developed/capital-rich countries which are also typical destinations of migrant workers from the developing nations." Hence, the featured life stories are also stories of the so-called globalization's discontents (Stiglitz, 2002), people who were unable to benefit from and/or left behind by the bonanza that neoliberal globalization brought to capitalist clans and corporations.

\section{Emilia: The Ambulant Vendor}

Emilia or "Miling" as others call her, is an elderly ambulant vendor, with very visible creases in her face burnt by daily exposure to the tropical sun in a not-so green city, Manila. As an elderly person (a "senior citizen" in the Filipino context), Miling is qualified to avail of the government's Social Pension Program for Indigent Senior Citizens (SPISC), a "government assistance in the amount of five hundred pesos monthly stipend," according to the Department of Social Welfare and Development website, but she tells the researchers she's not aware that such a program exists. She's not alone as "(s)ome $40 \%$ of Filipino senior citizens are still left behind in government efforts to provide social protection for the sector, based on estimates of the Coalition of Services of the Elderly (COSE)" (Pasion, 2017). Miling has been selling cigarettes, candies, snacks etc. as an ambulant vendor since 1995 - a 23-year experience of "hard work with no improvement" in her words. She's a co-breadwinner of her family of 6 : her sick husband, their only daughter (a part-time waitress) who's a single parent to their three grandchildren. In one of our conversations, Miling rails against tax hikes. She still remembers the time when the value-added tax (VAT) was expanded from 10 to $12 \%$ under the Macapagal-Arroyo regime and is disappointed when she learned that the Duterte administration's tax reform scheme made the price of major commodities including her wares - soar. She complains: "at times, noodles is all we can afford to eat. Or bread even in dinner time. Rice is expensive. Viands are expensive." Other Filipinos eat pagpag or recycled left-over food.

Miling reveals she voted for Duterte but is now not optimistic of the future, saying "they're all the same, no concern for the poor" (referring to various Philippine governments). She's especially incensed that life seems to be getting more miserable every year because of constant price hikes narrating: "When I started out in this job, commodities were still cheap. You can buy many things with just one peso. Now, 1,000 pesos feels like loose change." Like other ambulant vendors, she has suffered from the informality (or, as per the government's perspective, "illegality") of her occupation: "One time, the MMDA (Metro Manila Development Authority) personnel confiscated my wares. Yes, I know it's really illegal to sell things in the streets. But this is the only occupation I know. This is better than stealing or doing something bad." Miling's situation reflects the lives of many Filipino elderly citizens who are poor. 


\section{Josephine: The "Saleslady"}

Josephine is a permanent "saleslady" and minimum wage earner in a popular Metro Manila mall owned by one of the country's richest clans. As a minimum wage earner, she is with $1 / 3$ of the country's labor force (Habito, 2017). She remains single but "in a relationship" at 32. Somehow, Jo - as she calls herself - is lucky because many mall personnel are casuals or under zero-hour contracts. She got social and health insurance (SSS and Philhealth) but also dreams of paid vacations (few companies offer such benefits in the Philippines. Jo is a credit card pawner, a "Loandoner" (a play of words: from Londoner + loan $=$ Loandoner) as she says in local parlance, despite receiving a stable minimum wage: "what I earn is enough for our needs but I always pray that nobody in our family gets sick. Getting sick is a no-no. Be absent on just a day and you'll have deductions from your salary. My salary will then be not enough to cover our living expense." She belongs to the proverbial "isang kahig, isang tuka" (literally "one scratch, one peck") class - people who live through "hand-to-mouth existence." Not even retirement can offer her bliss. Her future SSS pension (pension fund for private employees in the Philippines) is very meager as the maximum pension at this point is just 10,900 pesos (De Vera, 2017). Jo works in a firm that will benefit from the government's prospective corporate tax cut from 30\% to $25 \%$ this year. Despite such possible tax cut and stable profits, corporations fail to share profits to workers. A relatively conservative profit-sharing bill languishes in Congress. For now, Jo will have to make do with what she has for herself and for her elderly parents too. Forced "overtime" during holidays and "sales" (discounts) periods do pad her pay but she admits: "I hate OT (overtime). Our hard work is not well compensated. It's not worth it but I can't complain." Even her typical hours seems to be unbearable: "I have to stand up all the time and I'm expected to greet customers and urge them to buy, buy and buy..."

\section{Mike: The Fastfood Worker}

Mike (not his real name as he refused to give his real first name) is a contractual worker in a major fastfood firm in the Philippines. He is a beneficiary of the Philippine Department of Labor and Employment's (DOLE) order to grant permanent status to 6,500 fastfood workers (Leonen, 2018). He is a minimum wage earner though he still considers himself "luckier than other workers" as his company provides free food (limited choices from the firm's own menu) during his shifts. Researchers' conversations with him veered towards food, owing to his job, and at one point, Mike casually remarks that fruits and vegetables are not part of his regular diet. He complains: "one starts to get sick of fastfood if its taken daily. Thus, I choose to bring my own food sometimes. Me and my co-workers share food when we bring some home-cooked meals." He expresses 
high hopes for the future: "I hope we really become regularized. May that DOLE order be implemented. I hope our salary gets hiked too." As of this writing, the DOLE ruling still stands and the fastfood firm affected by the order promises compliance, but the Philippine President - more than a week before the International Day of Labor this year - announced that he would no longer sign an executive order to end contractualization in the Philippines (a convenient campaign promise which has been rendered superfluous when Duterte is already in power, hobnobbing with capitalists, both local and foreign), claiming that it's up to Congress to ban the said hated policy which many firms utilize to save on costs at labor's expense. Mike is a young, 20-something "bedspacer" (one who co-rents a room with two or more persons) in Manila, renting at a rate of 2,000 per month. The said rent may sound cheap for expatriates but such "bedspace" is literally living in a small box, occupying space in double-decked beds, rather than living in a spacious home. To help him make both ends meet, he claims to have a "sideline" ("raket" is the Filipino word he used, which in the Filipino context generally refers to a legal "sideline," though it can also be used to refer to shadier occupations), but he declined to give details. Mike is originally from the Oriental Mindoro, where his peasant parents still reside. As the eldest child in a brood of 4 , he sends money to his parents whenever he can, to help support the needs of his younger siblings. Mike did not mention if his parents own the land that they till but many farmers in the Philippines are landless and the country's land reform program has been criticized for its hosts of failures (Sawchencko, 2000; Philippine Center for Investigative Journalism, 2015; Tadem, 2015; Manahan, 2011; Carranza, 2015). As a result, migration from rural to urban areas is still very common, as Mike's story illustrates.

\section{Nora: The Freelance Cleaner}

Nora is a middle-aged freelance cleaner in condominium units, who is married to a jeepney driver. She spreads word about her services through word of mouth, impressively earning an income above the minimum wage but nevertheless describes herself as "still poor," narrating: "My income is okay because my customers pay big tips. Sometimes, they double my rate. But somehow, my income is not enough because prices keep going up. I have medicines to take, maintenance medicine for high blood pressure. And we still pay for our children's education." Despite her complaints on rising prices and other tribulations common to the Filipino poor, she praiase her more generous customers, whom she says even treat her to free movie tickets: "Whenever I receive free tickets, my family goes to the cinema. We can't afford it if it's not free." They have two sons and one daughter. One just finished college and is now looking for a job, in a country where unemployment is generally worst in Southeast Asia. Two of their children are still in high school. At least, tuition in college would no longer be a problem because of the government's recently passed free tuition legislation, though various student 
groups warn that its implementation should be monitored to ensure that the poor benefits from it. Nora and her husband now only need to save for other universityrelated expenses. Their relatively secure situation could be unfortunately reversed by the fact that the government would soon phase out jeepneys (Bautista and Lema, 2018), possibly putting Nora's husband into unemployment, and Nora obviously can't be a cleaner forever. She admits with a hint of sadness: "my job is difficult. I suffer from arthritis at times. My joints ache but I need to be industrious always for our family."

\section{Ramon: The Security Guard}

Ramon is a security guard in a Manila midrise, approaching 40 years old, and married to a bank teller. He has two young children. He earns the minimum wage and resides in a rented apartment in Caloocan - one train ride and a jeepney ride away from his work place. He clocks in nearly 12 hours per day to earn overtime pay and make both ends meet, complaining that: "coffee no longer works in my case. I do some exercise, some stretching when I am sleepy. You can't be sleep, you can't be sleepy in our job.” The old labor slogan " 8 hours of work, 8 hours of rest, and 8 hours of recreation" has been overtaken by workers' poverty in the Philippines, and some German workers' successful fight for a 28 -hour week is still the exception, rather than the rule, these days. Ramon makes sure he still got time for his family despite his long work hours: "I always make time for them. We eat out, in the nearest mall, when it's my day of rest and when I have extra money." He dreams of buying their own house. He says commercial bank loans are definitely out of his options because of the high interest rates and the shorter loan terms. The Philippine government has the so-called Pag-ibig Fund, which provides loans for Filipino workers who want to buy their own houses, but his and his wife's combined income and their choice of house (a detached, non-socialized housing unit) are making things difficult for them, but Ramon says they're going to try again this year.

\section{Plan for Sustainable Development in the Philippines}

Sustainable development means development that is holistic, broad-based and egalitarian: development that will write better stories for the countless faces of poverty under the current system. The relationship between egalitarianism and sustainability is strong because the precisely inegalitarian nature of the current dominant economic system allows a tiny global elite to seemingly endlessly accumulate wealth at the expense of the environment and everyone else. Centuries of wealth accumulation of the elites worldwide have caused massive destruction in may parts of the globe, the effects of which are still being felt today through global warming and the extreme climate change that it brings. A world where a small group of clans and corporations are allowed to accumulate wealth without limitations for their equally endless luxuries and/or in pursuit 
of absurd goals such as growth for growth's sake, is a world without space for the needs of the poor majority - a ticking time bomb that is unsustainable and bound for collapse, if not already now on the verge of imminent apocalypse.

In the Philippines, the economic system can only become egalitarian if sweeping reforms towards broad-based development such as land reform, agricultural modernization, and industrialization are enacted. Such reforms are necessary for a Third World country to leapfrog into First World status, while ensuring environmental sustainability. To ensure that economic development and environmental sustainability are achieved together, full-blast research on and utilization of renewable energy is necessary. As a tropical archipelago surrounded by water, the Philippines is a prospective role model and leader in the field of renewable energy harnessed from the sun and the seas.

These sweeping reforms should be coupled with progressive tax reform - along the lines advocated by Karl Marx and Friedrich Engels in the Communist Manifesto and also advocated now even by non-Marxists like Thomas Piketty (2014) and Joseph Stiglitz (2013) - as only an egalitarian system will enable the government to lead initiatives in ensuring that accumulated wealth from ecnomic development is utilized for the people's essential needs and holistic enjoyment of life. Progressive taxation is a preliminary step towards a radically more holistic paradigm shift - from profit motive to people- and Earth-centeredness, from endless macroeconomic growth and elite wealth accumulation to sustainable development and wealth redistribution, from strengthening corporations to empowering communities - a shift that will genuinely precipitate sustainable development for current and future generations.

\section{References}

Alston, P. (2017). Statement on Visit to the USA by the United Nations Special Rapporteur on extreme poverty and human rights. http://www.ohchr.org/EN/NewsEvents/Pages/DisplayNews.aspx?NewsID=22533\&LangID=E

Bautista, R. and K. Lema. (2018). Philippines to phase out its beloved cheap but rickety jeepneys. Reuters. https://www.reuters.com/article/us-philippines-transport-jeepneys/philippines-to-phase-out-itsbeloved-cheap-but-rickety-jeepneys-idUSKBN1FI0IJ

Carranza, D. (2015). Agrarian reform and the difficult road to peace in the Philippine countryside. https://reliefweb.int/sites/reliefweb.int/files/resources/Carranza NOREF Agrarian $\% 20$ reform $\% 20$ and $\% 20$ the $\% 20$ difficult $\% 20$ road $\% 20$ to $\% 20$ peace $\% 20$ in $\% 20$ the $\% 20$ Philippine $\% 20$ countrysid e Dec2015 FINAL.pdf

Chandy, L. and H. Kharas. (2012). The Contradictions in Global Poverty Numbers. Brookings. https://www.brookings.edu/opinions/the-contradictions-in-global-poverty-numbers/.

Chossudovsky, M. (2018). Poverty in the Philippines: The Official Figures Have Been Manipulated. https://www.globalresearch.ca/world-bank-on-philippines-economy/5628035.

De Vera, B. (2017). SSS: Proposed hike in monthly salary credit cap will raise pension payments. Inquirer. http://business.inquirer.net/238685/sss-proposed-hike-monthly-salary-credit-cap-will-raisepension-payments 
Dela Paz, C. (2016). What's ideal monthly income for family of 4?. https://www.rappler.com/business/economy-watch/137891-ideal-monthly-income-neda-2040vision.

Department of Energy. (2018). HOUSEHOLD LPG PICK-UP PRICES IN METRO MANILA. https://www.doe.gov.ph/sites/default/files/pdf/price watch/lpg mm 2018 march 09.pdf

Department of Trade and Industry. (2017). Weekly Prevailing Report. http://opms.dti.gov.ph/consumer/weekly-prevailing

Eurostat. (2015). Quality of life indicators - leisure and social interactions. http://ec.europa.eu/eurostat/statistics-explained/index.php/Quality of life indicators leisure and social interactions.

Food and Nutrition Research Institute. (c. 2018). Daily Nutritional Guide Pyramid for Adults. http://www.fnri.dost.gov.ph/index.php/tools-and-standard/nutritional-guide-pyramid\#adults20-39yrs-old

Gawin Group. (2017). How Much Does Plumbing Repair Cost?. http://direct.gawin.ph/priceestimates/plumbing-and-pipe-leaks-repair-pricing/

Habito, C. (2017). Profile of the Filipino worker. Inquirer. http://opinion.inquirer.net/103546/profilefilipino-worker

Hickel, J. (2016). The true extent of global poverty and hunger: questioning the good news narrative of the Millennium Development Goals. Third World Quarterly 37:5, 749-767, DOI: 10.1080/01436597.2015.1109439

Ibon Databank. (2017). Substantially increase wages. http://ibon.org/2017/01/substantially-increase-wages/ Human rights, leisure and leisure studies

Leonen, J. (2018). Jollibee to appeal Dole's order to regularize about 6,500 workers. Inquirer. http://business.inquirer.net/248588/jollibee-appeal-doles-order-regularize-6500workers\#ixzz5DT500G4s

Leversen, I. (2012). Basic Psychological Need Satisfaction in Leisure Activities and Adolescents' Life Satisfaction. Journal of Youth and Adolescence, 41: 12, 1588-1599,

https://www.ncbi.nlm.nih.gov/pmc/articles/PMC3492701/

Leyco, C. (2018). PH to attain status of upper middle-income in 2019 - NEDA. Manila Bulletin. https://business.mb.com.ph/2018/04/03/ph-to-attain-status-of-upper-middle-income-in-2019neda/.

Manahan, M. A. (2011). Banking on the Rural Poor?: Critical Insights and Policy Questions on Foreign Aid And Agrarian Reform in the Philippines. Kasarinlan: Philippine Journal of Third World Studies, 26:1-2, 312-323, journals.upd.edu.ph/index.php/kasarinlan/article/download/3502/pdf 140

Mangahas, M. (2011a). The lowering of the official poverty line.

http://www.sws.org.ph/social climate/2011/PDI\%201106\%20Feb $\% 2012 \% 20$ The $\% 20$ lowering $\% 20$ of $\% 20$ the $\% 20$ official $\% 20$ poverty $\% 20$ line.pdf

Mangahas, M. (2011b). No meat allowed for the poor. Inquirer. http://opinion.inquirer.net/14829/nomeat-allowed-for-the-poor

Manila Electric Company. (2018). Meralco Appliance Calculator. http://apps.meralcwo.com.ph/appcal/mac.jsp.

Maynilad. (2018). Bill Calculator. http://www.mayniladwater.com.ph/customers-bill calculator.php

Moatsos, M. (2017). Global Absolute Poverty: Behind the Veil of Dollars. Journal of Globalization and Development, 7:2, 1-28, https://doi.org/10.1515/igd-2016-0033.

National Statistical Coordination Board. 2007. NSCB Resolution No. 2 Series of 2007 APPROVING AND ADOPTING THE OFFICIAL CONCEPTS AND DEFINITIONS FOR STATISTICAL $\begin{array}{llll}\text { PURPOSES FOR } & \text { THE }\end{array}$ http://nap.psa.gov.ph/resolutions/2007/2Annexb.asp.

Numbeo. (2018). Cost of Living in Manila. https://www.numbeo.com/cost-of-living/in/Manila

Ostry, J. et al. (2016). Neoliberalism: Oversold?. Finance \& Development, Vol. 53, No. 2. International Monetary Fund. http://www.imf.org/external/pubs/ft/fandd/2016/06/ostry.htm.

Pasion, P. (2017). 4 in 10 senior citizens still have no access to pension - COSE. Rappler. https://www.rappler.com/nation/184363-philippines-senior-citizens-no-access-pension-cose

Pe-Pua, R. and E. Protacio-Marcelino. (2000). Sikolohiyang Pilipino (Filipino psychology): A 
legacy of Virgilio G. Enriquez. Asian Journal of Social Psychology, 3: 49-71, https://onlinelibrary.wiley.com/doi/pdf/10.1111/1467-839X.00054

Philippine Center for Investigative Journalism. (2015). CARP, CARPER: Failing, falling, dead?. http://pcij.org/blog/2015/06/11/carp-carper-failing-falling-dead

Philippine Statistics Authority. (2015). 2015 POVERTY IN THE PHILIPPINES. https://psa.gov.ph/sites/default/files/2015 povstat FINAL.pdf

Philippine Statistics Authority. (2017). Preliminary Results of the 2017 Annual Estimates of Labor Force Survey (LFS). https://psa.gov.ph/content/2017-annual-labor-and-employment-status

People's Television. 2016a. Price watch sa Divisoria. https://www.youtube.com/watch?v=WmLaTy8rSwE.

People's Television. 2016b. Price Watch: Footwear prices sa Divisoria. https://www.youtube.com/watch?v=KplN7hkNRsM.

Piketty, T. (2014). Capital in the twenty-first century. Massachusetts: Belknap Press.

Reddy, S. \& R. Lahoti. (2016). \$1.90 A DAY: WHAT DOES IT SAY?. New Left Review, 97, JanuaryFebruary, 106-127. https://newleftreview.org/II/97/sanjay-reddy-rahul-lahoti-1-90-a-day-what$\underline{\text { does-it-say }}$

QualiMed. (c.2018). Health Cards. http://qualimed.com.ph/products-and-services/membership-cards-3/

San Juan, D.M. (2016). Neoliberal Restructuring of Education in the Philippines: Dependency, Labor, Privatization, Critical Pedagogy, and the K to 12 System. Asia-Pacific Social Science Review. 16: 1, 80-110, https://ejournals.ph/article.php?id=9857

San Juan, D.M. (2017). Why Marx Was Right: Third World Edition. Journal of Developing Societies, 33:1, 1-26, http://journals.sagepub.com/doi/pdf/10.1177/0169796X16653333

Saunders, P. (2018). Monitoring and addressing global poverty: A new approach and implications for Australia. The Economic and Labour Relations Review, 29:1, 9-23, http://journals.sagepub.com/doi/abs/10.1177/1035304618756208

Sawchenko, A. (2000). Choosing a Mechanism for Land Redistribution in the Philippines. Pacific Rim Law and Policy Journal, 9:3, 681-720, https://digital.lib.washington.edu/dspacelaw/bitstream/handle/1773.1/822/9PacRimLPolyJ681.pdf?sequence $=1$ \&isAllowed $=\mathrm{y}$

Smart. (2018). 30 to 60 Days Call, Text, Data Promos. https://smart.com.ph/Prepaid/promos/validity/3060-days

Stiglitz, J. (2002). Globalization's and its discontents. New York: W. W. Norton \& Company.

Stiglitz, J. (2013). The price of inequality: How today's divided society endangers our future. New York: W. W. Norton \& Company.

Tadem, E. (2015). Philippine Agrarian Reform in the 21st Century. https://www.iss.nl/sites/corporate/files/CMCP D2-Tadem.pdf

Veal, A.J. (2015). Human rights, leisure and leisure studies. World Leisure Journal, 57: 4, 249-272, DOI: 10.1080/16078055.2015.1081271

World Bank. (2013). US Poverty headcount ratio at $\$ 1.90$ a day (2011 PPP) (\% of population). https://data.worldbank.org/topic/poverty?locations=US\&view $=$ chart. 